\title{
Using Meigen's staining for aragonite-calcite identification in fossil molluscan shells under the scanning electron microscope
}

\author{
Seiichi Suzuki*, Yoshihiro Togo** and Yoshinori Hikida*
}

\begin{abstract}
A staining method was successfully examined to distinguish aragonite from calcite in the fossil shells of some Cenozoic molluscs under the scanning electron microscope (SEM). The internal morphology and mineral phase of the shells can be observed simultaneously by this method. The most suitable preparation was found in the samples which were polished, etched and stained with Meigen's solution for ten minutes at $70^{\circ} \mathrm{C}$. In the samples very fine $(0.03 \mu \mathrm{m}$ wide, $0.2 \mu \mathrm{m}$ long) fibril-like materials forming thin sheets are selectively precipitated on the aragonite areas, although a small amount is formed on the marginal zones of the calcite areas. The original texture of the aragonite is distinguishable through the sheet because of the small dimensions of the materials precipitated on the crystals. The fibril-like deposits contain a large amount of cobalt derived from the staining solution, therefore, the identification of the minerals is supported by information from the backscattered electron image and by energy dispersive X-ray spectrometry (EDS). The cobalt precipitation can also indicate strontian aragonite crystals occasionally deposited within the cavities of the shells, the characteristics of the aragonite being reconfirmed by the EDS and X-ray diffractometry. Any applications of Feigl's staining to the aragonite-calcite dentification were not successful in this study, because the large sizes of the precipitated grains $(1-2 \mu \mathrm{m}$ in diameter) prevented precise distinction of the minerals under SEM.
\end{abstract}

Key words: aragonite, calcitization, fossil shell, Meigen's staining, SEM observation, EDS analysis

\section{Introduction}

All adult molluscan shells contain at least one aragonitic shell layer, and in many cases the shells are wholly aragonitic (Taylor et al., 1969, 1973; Carter, 1980; Togo \& Suzuki, 1988; Lowenstam \& Weiner, 1989). In the process of fossilization, in particular, aragonite shells are easily converted to calcite during diagenesis, because of the metastability of aragonite under conditions of low temperature and low pressure (Tucker, 1991). Original aragonitic shell struc-

Received November 20, 1991. Accepted October 22, 1992.

* Department of Earth Sciences and Astronomy, Fukuoka University of Education, Munakata 81141, Japan.

** Department of Each Sciences, Iwamizawa College, Hokkaido University of Education, Iwamizawa 068, Japan. tures are generally destroyed to varying degrees along with this conversion.

However, preservation of the original structures can be observed in mineralogically unaltered shells, although fusion, dissolution or fragmentation of the aragonite crystallites of the original shell are sometimes recognized (Togo \& Suzuki, 1987). Moreover, the original structures remain within shells converted to calcite, being similar to a "pseudomorph" of calcite after aragonite.

The visual distinction of aragonite from calcite is very difficult in hand specimens or under the light microscope (LM) because of the similarity of optical and other physical properties. Some staining methods have, therefore, been used for differentiating between both carbonate minerals under the LM (summarized by Friedman, 1959). Meigen's staining (also known as Meigen's reaction) is a conventional method for aragonite determination since its introduction by Holmes 
(1921). However, Friedman (1959) did not recommend this method, because Jirova (1956) reported that Meigen's staining applied to the tests of three species of the Foraminifera indicated aragonite, but X-ray powder patterns showed calcite. On the other hand, some researchers have shown that Meigen's staining works quite well in the aragonite-calcite identification with the naked eye or under the LM (Togari \& Togari, 1955; Kamiya, 1975, 1978). Staining with Feigl's solution is also reliable for visual aragonite identification

Based on current methods the determination of aragonite and calcite is impossible under the scanning electron microscope (SEM) without analysis of X-ray diffraction of the fragments taken from the specimen same as that for SEM observations. Schneiderman \& Sandberg (1971) tried Feigl's staining for electron microscope studies to enable both the mineral phase and morphology to be observed simultaneously. However, Reed-Miller et al. (1980) pointed out that this method is difficult to use and not totally reliable in its application. Moreover, Dickson (1985) has reported that the unreliability is due to grain size effects.

For the immediate identification of aragonite under the SEM, we tried to apply these two staining methods used for the LM to the preparation for the SEM observations. In this paper we will describe a suitable staining method for aragonite in calcitized fossil shells without any important changes of the microstructures. The methods examined in this study are useful for samples composed of aragonite and calcite which are incapable of being discriminated by the LM, or cannot be mechanically separated because of small quantities and dimensions, or complexity of contacts.

\section{Materials and methods}

Materials Two types of fossil specimens were used in this study. One of them was collected from the Late Oligocene-Early Miocene Ashiya Group in Fukuoka and Yamaguchi Prefectures (Tomita \& Ishibashi, 1990). Although many patterns of fossilization are recognized in these areas, it is very common that originally aragonitic shells have been converted to calcitic ones. This conversion is often imperfect in some fossils; many shells of Glycymeris cisshuensis, which are originally constructed of crossed lamellar and complex crossed lamellar aragonites, are imperfectly converted and are useful for this study. The other specimens were taken from the Middle Miocene Masuda Group in Shimane Prefecture. Some fossils from an outcrop of the Masuda Group are characterized by the precipitation of strontian aragonite crystals $\left(4.54 \mathrm{~mol}^{2} \mathrm{SrCO}_{3}\right.$ on the average) within the shell cavities (Suzuki et al., 1990). Some gastropod shells, which are originally aragonitic, are also imperfectly converted to calcitic shells. Strontium contents in the aragonite part of the shell $(0.26 \mathrm{~mol} \%$ on the average) are slightly richer than those of any living shells and of the shells from the Ashiya Group. Among the fossil molluscs yielded, the gastropods Vicarya japonica and Tateiwaia sp. were used. The original shells are mainly formed by a crossed lamellar structure.

Methods To ensure a good state of preparation, we attempted to examine the specimens under several conditions of polishing (finally with an alumina suspension containing grains of $0.3 \mu \mathrm{m}$ in diameter), etching (with a $0.5 \mathrm{~mol}$ EDTA solution, $\mathrm{pH} 7.2$ ) and staining. Two methods were used for the staining of aragonite, treatments with Meigen's solution and with Feigl's solution. A $10 \%$ cobalt nitrate $\left(\mathrm{Co}\left(\mathrm{NO}_{3}\right)_{2}\right)$ solution was prepared for Meigen's staining (Kamiya, 1975). A Feigl's solution (the mixture of silver sulfate $\left(\mathrm{Ag}_{2} \mathrm{SO}_{4}\right)$ and manganese sulfate $\left(\mathrm{MnSO}_{4}\right)$ with dilute sodium hydroxide $(\mathrm{NaOH})$ solution) was made in the ordinary proportion reported by Friedman (1959). Stained specimens were first observed under the binocular microscope, then they were coated with gold or carbon and observed under the SEM (JEOL JSM-5200) at 15 or $20 \mathrm{kV}$. These observations were supported by analyses of elemental components with an energy dispersive $\mathrm{X}$-ray spectrometer (EDS: JEOL JED-2000) attached to the SEM. The mineralogy of the specimens was reconfirmed by X-ray diffractometry.

\section{Results}

\section{Staining with Meigen's solution}

Simultaneous observation of the original tex- 
Table 1. Summary of sample preparations and results of stainings for aragonite.

\begin{tabular}{|c|c|c|c|c|c|c|c|c|}
\hline \multirow{2}{*}{\multicolumn{2}{|c|}{ Etching periods (min.) }} & \multicolumn{4}{|c|}{ Meigen's staining } & \multicolumn{3}{|c|}{ Feigl's staining } \\
\hline & & 15 & 15 & 15 & 0 & 15 & 15 & 0 \\
\hline \multicolumn{2}{|c|}{ Staining periods (min.) } & 7 & 10 & 15 & 15 & 10 & 7 & 10 \\
\hline \multicolumn{2}{|c|}{ Staining temperature $\left({ }^{\circ} \mathrm{C}\right)$} & 65 & 70 & 80 & 80 & 22 & 70 & 22 \\
\hline \multicolumn{2}{|c|}{ Color pattern } & $\begin{array}{l}\text { pale } \\
\text { purple }\end{array}$ & purple & $\begin{array}{l}\text { deep } \\
\text { purple }\end{array}$ & $\begin{array}{l}\text { lavender } \\
\text { blue }\end{array}$ & black & black & $\begin{array}{l}\text { parti- } \\
\text { colored }\end{array}$ \\
\hline \multirow{2}{*}{$\begin{array}{l}\text { SEM } \\
\text { observation }\end{array}$} & Texture & O & O & $x$ & $x$ & $\triangle$ & $\triangle$ & $x$ \\
\hline & Mineral phase & $\triangle$ & $\bigcirc$ & $\triangle$ & $x$ & $\triangle$ & $\triangle$ & $x$ \\
\hline \multicolumn{2}{|c|}{ EDS analysis } & $\triangle$ & $\bigcirc$ & $\triangle$ & $\triangle$ & $\triangle$ & $\triangle$ & $x$ \\
\hline
\end{tabular}

: good, $\triangle$ : possible but unstable or difficult, $X$ : impossible

ture and mineral phase was successfully obtained by staining with Meigen's solution. Actual applications of this staining to the SEM observations required certain conditions of preparation, such as etching and staining periods, and temperature of solution. Although previous workers (Togari \& Togari, 1955; Kamiya, 1975) reported that boiling the staining solution was necessary, aragonite parts of the specimens used in this study were sufficiently stained with unboiled solutions. As the result of many tests under various conditions, the most suitable preparation was found in the sample which was polished, etched for fifteen minutes, and then stained for ten minutes at $70^{\circ} \mathrm{C}$ (Table 1 ).

In the samples of Glycymeris cisshuensis treated with this preparation, the sectioned surfaces of the aragonite are splendidly painted in purple, while those of the calcite appear uncolored. Under the SEM, fibril-like materials $(0.03 \mu \mathrm{m}$ in width, $0.2 \mu \mathrm{m}$ in length) are selectively attached to the surfaces of aragonite and they form a thin sheet by combining with each other (Plate I-3,4). Each sheet has cracks approximately aligned with the arrangement of the underlying aragonitic microstructure (Plate I-1). The original texture of the aragonite parts is recognizable through the sheet, because of the fineness of a coating sheet. For example, each third-order lamella of the crossed lamellar structure is easily distinguished from its neighbors (Plate I-2). Near the boundary between aragonite and calcite, fibril-like materials are also found on the calcite area, but they abruptly disappear at the position considerably away from the boundary. In the calcite area etched patterns reflecting the original shell microstructure of aragonite are often observable, but fibril-like materials are not precipitated there (Plate II-1).

The contrast in brightness between the aragonite and calcite areas is much more distinct in the backscattered electron (compositional) image than that in the secondary electron (common SEM) image (Plate II-2, Plate III-1), indicating the high density of fibril-like materials on the aragonites. However, if there is no change in the accelerating voltage, the details of the adherent materials cannot be obtained from the backscattered electron image, because the resolution of the image becomes inferior, in general at a magnification higher than about 3,000 times. EDS analyses confirm that fibril-like materials contain only Co derived from the metal element of the staining solution (Plate III-2). Calcium is not detected from the treated aragonite parts appearing to be masked by fibril-like materials. On the other hand, Co is not found from the calcite parts except in the marginal zone, but $\mathrm{Ca}$ is always found (Plate III-3). In the marginal zone $\mathrm{Co}_{0}$ is also detected together with $\mathrm{Ca}$. The amount of 


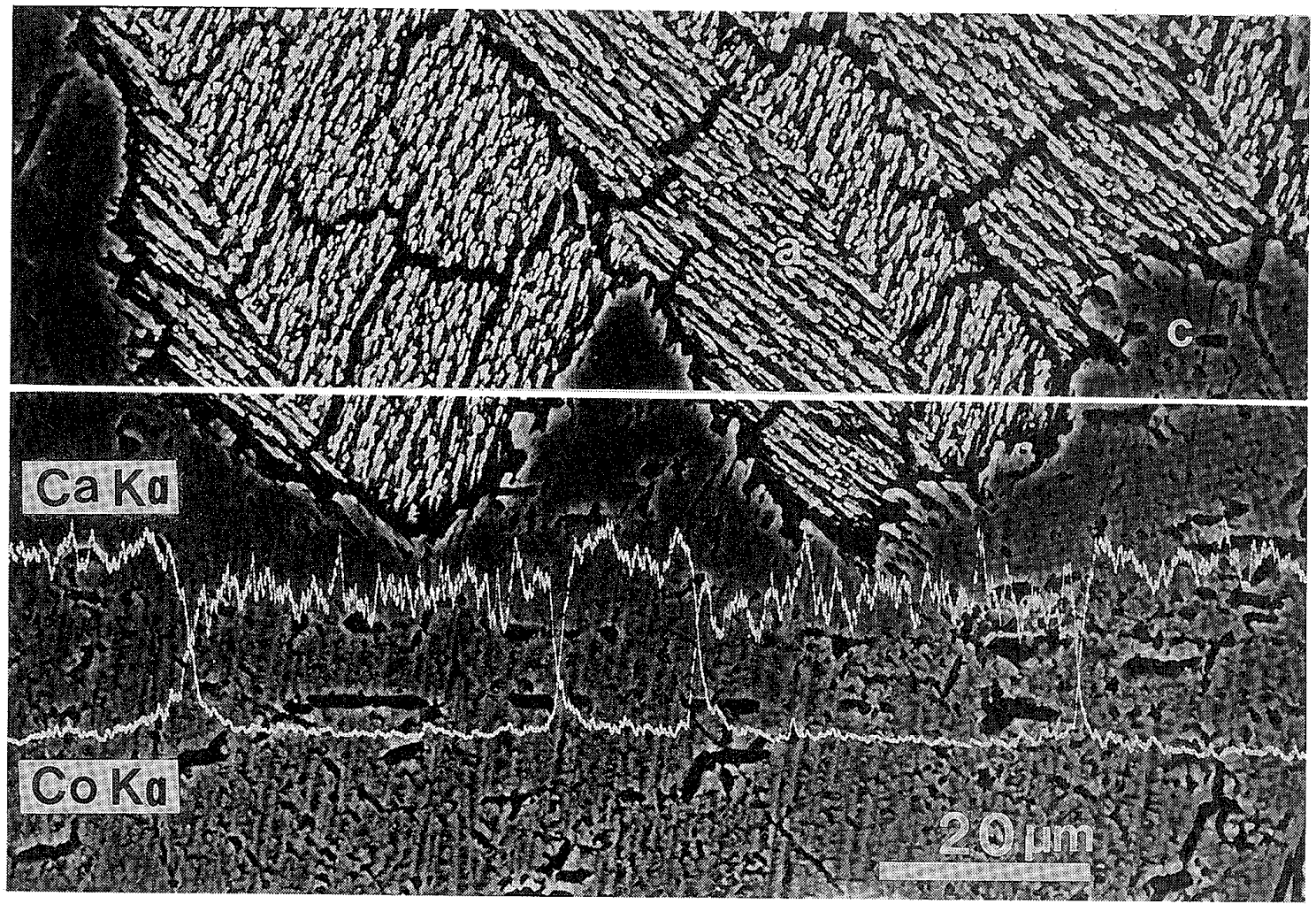

Fig. 1. Line profiles of the X-ray spectra across the aragonite (a) and calcite (c) areas in the sample stained with a Meigen's solution. Cobalt detected only from the aragonite area is well contrasted by calcium from the calcite.

Co in this zone are very small, so that line profiles of the X-ray spectra of both elements change sharply at the boundaries between aragonite and calcite areas (Fig. 1).

The specimens of Vicarya japonica and Tateiwaia sp., which were composed of original aragonite and replacing calcite in the shell, and of strontian aragonite precipitated within the shell cavity, were treated in the same way as mentioned above. Only the aragonite areas of the shell are stained in purple, but the other areas do not appear colored to the naked eye. The area of strontian aragonite, however, appears to be coated by somewhat colorless membranes under the binocular microscope. SEM observations reveal that this area is completely covered by the sheets of fibril-like materials, the same as in the aragonite areas (Plate II-4). EDS analyses also indicate that the sheets contain a large amount of $\mathrm{Co}$.

The staining period and temperature control the amount of fibril-like materials without influencing the size of the fibrils. For example, in the sample stained for fifteen minutes at $80^{\circ} \mathrm{C}$, aragonite areas (and perhaps their peripheries) are colored in deep purple. Under the SEM, comparatively thick sheets of fibril-like materials cover both the aragonite and the marginal zones of the calcite areas, and are cracked with no relation to the underlying substance (Plate II-3), so that the original texture and rigid boundaries of the minerals in the sample are obscured. On the other hand, in the sample stained for seven minutes at $65^{\circ} \mathrm{C}$ aragonite areas are colored in pale purple. Because the amount of adherent materials is too small, the SEM observations clarify the original texture of the sample, but the EDS determination of mineralogy becomes much more difficult because of the detection of a considerable amount of $\mathrm{Ca}$ from both the calcite and aragonite areas.

As mentioned above, the depth of color usually indicates the amount of fibril-like precipitates, but it is recognized that the color pattern itself is also influenced by the surface conditions of 
samples. In the case of the sample polished without any etching, and stained for fifteen minutes at $80^{\circ} \mathrm{C}$, the aragonite areas are faced in light lavender blue. This faint color, however, does not mean a slight precipitation of the element, because the SEM image shows that fibril-like materials form a thick sheet on the aragonite area and its periphery. This sheet is severely cracked and heavily curled up. When observed on the curled-back portions, aragonite crystals are directly exposed beneath the sheet.

\section{Staining with Feigl's solution}

When staining with Feigl's solution under various conditions of preparation, we also used many samples from the same specimens as examined by Meigen's staining. However, we have not found this method to be more effective than Meigen's staining. The etching effect is remarkable even to the unaided eye. For example, in the sample polished, etched for fifteen minutes and stained for ten minutes at room temperature (about $22^{\circ} \mathrm{C}$ ), aragonite areas are selectively and homogeneously colored in black. In the unetched samples, on the other hand, this method appears unstable, the aragonite areas being sometimes partially colored and sometimes unpainted. However, for SEM identification, even the macroscopically well-prepared sample is not appropriate; under the SEM many grains $(1-2 \mu \mathrm{m}$ in diameter) are precipitated on the surfaces of the aragonite parts and considerable numbers of such grains are also scattered on the calcite parts, especially on the grooved and/or porous areas (Plate II-5). The rigid boundary between aragonite and calcite is, therefore, not always recognized. Because of the size effect of the grains, detailed observation of the aragonite texture is also prevented. Each grain is formed by the aggregation of very fine particles of less than $0.1 \mu \mathrm{m}$ in diameter (Plate II-6). The isolation of particles was examined by heating the staining solution up to $70^{\circ} \mathrm{C}$, but particles were rarely isolated from each other by this technique. The EDS analysis shows that these grains (or particles) contain $\mathrm{Ag}, \mathrm{Mn}$ and $\mathrm{S}$ derived from the staining solution. Strontian aragonite is also stained with this solution, being the same as the ordinary aragonite mentioned above, but the staining is not suitable for SEM identification.

\section{Summary}

As the results show, aragonite parts within calcitized fossil shells are successfully identified under SEM by means of the staining technique, Meigen's staining. Our examinations suggest that this method is certainly useful for the visual identification of aragonite whether or not the mineral contains trace elements such as strontium, when the preparations of the samples and the conditions of the staining solution are appropriate. The color pattern does not always indicate the amounts of adherent materials, appearing to be effected by the surface conditions of the samples; a flattened surface tends to be stained in a light color as mentioned above in the unetched sample. The colorlessness in the case of the stained strontian aragonite is probably due to the same reason, because its polished and etched surface is not so complex. The method examined in this study is not influenced by the surface conditions which may effect staining property and is practical for SEM observations. When observing with the SEM, we can analyse the minerals morphologically at the level of $10^{-1}$ micrometer because of the smaller size of the precipitates.

We also tried Feigl's staining for aragonite identification under the SEM. This staining method was examined under several conditions to attempt to eliminate grain size effects, but were unable to find a good, size-effect-free condition.

The Meigen's staining examined for the SEM observations is successful not only for fossil skeletons, but could be possibly applied to, for example, carbonate cements formed within some sedimentary rocks, carbonate minerals occurring as a primary phase in high-pressure metamorphic rocks, calcareous sinters deposited from thermal waters, etc. On the other hand, our staining was performed under the condition that specimens were not in the boiled solution conventionally used, but in a solution maintained at the temperature of $70^{\circ} \mathrm{C}$. Solution at this temperature will identify the minerals and clarify the relationships between organic and mineral phases in living adult, larval and regenerated skeletons, 
which usually show complicated arrangement in ultrastructure, because comparatively low temperature may result in less damages to organic materials.

Acknowledgments We wish to express our sincere gratitude to Professor Emeritus Satoru Uozumi of Hokkaido University for his continuous guidance and kind encouragement during the course of this study. We also thank Mr. Iwao Takasu of Fukuoka University of Education for his technical assistance. This study was partly supported by the Grant-in-Aid for Scientific Research from the Ministry of Education, Science and Culture (No. 01540644).

\section{References}

Carter, J. G., 1980, Environmental and biological controls of bivalve shell mineralogy and microstructure. In Rhoads, D. C. and Lutz, R. A., eds., Skeletal growth of aquatic organisms. Prenam Press, New York, 69-113.

Dickson, J. A. D., 1985, Diagenesis of shallow-marine carbonates. In Brenchley, P. J. and Williams, B. P. J., eds., Sedimentology: recent developments and applied aspects. Blackwell Sci. Pub., Oxford, 173-188.

Friedman, G. M., 1959, Identification of carbonate minerals by staining methods. Jour. Sediment. Petrol., 29, 87-97.

Holmes, A., 1921, Petrographic methods and calculations. Thomas Murby and Company, London, 262p.

Jirova, D., 1956, Modifications of $\mathrm{CaCO}_{3}$ in the shells of foraminifera. Casopis Mineral. Geol., 1, 101-104.

Kamiya, H., 1975, Study on the diagenetic and experimental alteration of some aragonitic shells - Basic researches concerning the early process of their fossilization. Sci. Rep. Tokyo Univ. Educ., Ser. C, 12, 177-211.

- 1978, Selective alteration of the shell forming minerals observed in some fossils and heated shells. Earth Science (Chikyu Kagaku), 32, 236-243.*

Lowenstam, H. A. and Weiner, S., 1989, On biomineralization. Oxford Univ. Press, New York, $324 \mathrm{p}$.

Reed-Miller, C., Wise, S. W. and Siegel, H. J., 1980,
Correlated techniques for identifying mineral phases and morphologies in regenerated archaeogastropod shell: a progress report. In Omori, $\mathrm{M}$. and Watabe, N., eds., The mechanisms of biomineralization in animals and plants. Tokai Univ. Press, Tokyo, 73-77.

Schneiderman, N. and Sandberg, P. A., 1971, Calcitearagonite differentiation by selective stainings and scanning electron microscopy. Trans. Gulf Coast Assoc. Geol. Soc., 21, 349-352.

Suzuki, S., Yamada, K. and Togo, Y., 1990, Strontian aragonite precipitated in the cavities of some molluscan shells from the Middle Miocene Masuda Group, Shimane Prefecture. Jour Geol. Soc. Japan, 96, $873-876$.**

Taylor, J. D., Kennedy, W. J. and Hall, A., 1969, The shell structure and mineralogy of the Bivalvia: Introduction, Nuculacea-Trigonacea. Bull. Brit. Mus. Nat. Hist., Zool., Suppl., 3, 1-125.

- $\longrightarrow$ and $\longrightarrow, 1973$, The shell structure and mineralogy of the Bivalvia II: Lucinacea-Clavagellacea, conclusions. Bull. Brit. Mus. Nat. Hist., Zool., 22, 255-294.

Togari, K. and Togari, S., 1955, Conditions controlling the crystal form of calcium carbonate minerals (1). Jour. Fac. Sci., Hokkaido Univ., Ser. IV, 9, 55-65.

Togo, Y. and Suzuki, S., 1987, Non-skeletal aragonite precipitated within conglomerate and altered invertebrate skeletons from the Plio-Pleistocene Setana Formation, Hokkaido. Jour. Geol. Soc. Japan, 93, 149-151.

$\longrightarrow$ and —, 1988, Shell structure and phylogeny of the Gastropoda. In Omori, M., Suga, S. and Goto, M., eds., Biomineralization and phylogeny of marine organisms. Tokai Univ. Press, Tokyo, 113$134 . * *$

Tomita, S. and Ishibashi, T., 1990, Review of the geology and paleontology of the Paleogene coal-fields in North Kyushu. Sci, Rep. Dept. Geol., Kyushu Univ., 16, $99-142$ *

Tucker, M. E., 1991, The diagenesis of fossils. In Donovan, S. K., ed., The processes of fossilization. Belhaven Press, London, 84-104.

* : in Japanese with English abstract.

**: in Japanese. 
Suzuki, S., Togo, Y. and Hikida, Y., 1993, Using Meigen's staining for aragonite-calcite identification in fossil molluscan shells under the scanning electron microscope. Jour. Geol. Soc. Japan, 99, 1-7. (鈴木清一・都鄉義寬・正田吉識, 1993，走查型電子顕微鏡による化石軟体動物 殼体中のアラレ石一方解石の同定へのマイゲン氏染色法の応用一．地質雑，99，1-7.)

染色法を応用して，化石貝殼内のアラレ石と方解石の識別と，内部構造観察を走查型電子顕微鏡下 で同時に行えるようにした.マイゲン氏法とフイーグル氏法を試みたが, 前者の染色法で, 試料のエッ チング処理, 染色時間 10 分, 液温 $70^{\circ} \mathrm{C}$ の条件下で好結果を得た. マイゲン氏染色により，アラレ 石部および高 Sr アラレ石部には微細な繊維状物質からなる薄膜が沈着し，方解石部と区別される. 沈着物は微細で極薄なために, 殼体構造の識別も可能である. 沈着物はアラレ石部に隣接する方解石 部周縁にも認められるが，少量なため，反射電子組成像観察や，エネルギー分散型元素分析装置によ る染色液由来の Co の濃度分布測定などを併用すると, 鉱物相の判別が容易になる.また，フィーグ ル氏法を種々の液温下で試みたが, 沈着物が凝集して粗粒化するために, 好結果を得られなかった。

\section{Explanation of Plates}

All figures are of the fossil shells of Glycymeris cisshuensis except for Plate II-4. Scale bars in micrometers. a: aragonite, c: calcite, sa: strontian aragonite.

Plate I. Scanning electron micrographs (secondary electron images) of the samples polished, etched and stained with a Meigen's solution for ten minutes at $70^{\circ} \mathrm{C}$.

1. Transverse section showing thin sheets of precipitations coating the surfaces of aragonite areas. Note the cracks in the sheets along with the arrangement of the underlying crystals.

2. Radial section showing third-order lamellas (acicular aragonites) of the crossed lamellar structure recognizable through the sheet.

3. High magnification of the aragonite area in contact with calcitized areas. Fine precipitations are found on the aragonite crystals and not on the calcite except the margin.

4. Much higher magnification of the aragonite area. The precipitates are formed by a network of fibril-like materials.

Plate II. Secondary and backscattered electron images of various samples stained with Meigen's or Feigl's solution.

1. Secondary electron image of the calcitized crossed lamellar layer of the same sample as shown in Plate I-1. The calcitic microstructure of the layer, which may be aragonitic in the original shell, is free from precipitations (Meigen's staining for ten minutes at $70^{\circ} \mathrm{C}$ ).

2. Backscattered electron image of the aragonite and calcite areas of the same sample as shown in Plate I-1. Cobalt deposited on the aragonite areas ensures easy distinction between both minerals (Meigen's staining for ten minutes at $70^{\circ} \mathrm{C}$ ).

3. Backscattered electron image of the sample stained with Meigen's solution for fifteen minutes at $80^{\circ} \mathrm{C}$. Comparatively thick sheets cover not only the aragonite areas but also marginal and isolated zones of the calcite areas, preventing observation of the fine texture of underlying minerals.

4. Backscattered electron image of the sample from Tateiwaia sp. stained with Meigen's solution for ten minutes at $70^{\circ} \mathrm{C}$. Note the stained strontian aragonite crystals within the shell cavity.

5. Secondary electron image of the sample stained with Feigl's solution for ten minutes at $22^{\circ} \mathrm{C}$. Many grains are precipitated on both the aragonite and calcite areas.

6. Higher magnification of Plate II-5 showing grains composed of aggregations of finer particles. Plate III. X-ray distribution images corresponding to the backscattered electron image of the sample stained with Meigen's solution for ten minutes at $70^{\circ} \mathrm{C}$.

1. Backscattered electron image (BEI) showing the aragonite and calcite areas analysed with EDS.

2,3. X-ray distribution images showing cobalt $(\mathrm{CoK} \alpha)$ detected only from the aragonite area and calcium $(\mathrm{CaK} \alpha)$ from the calcite. 

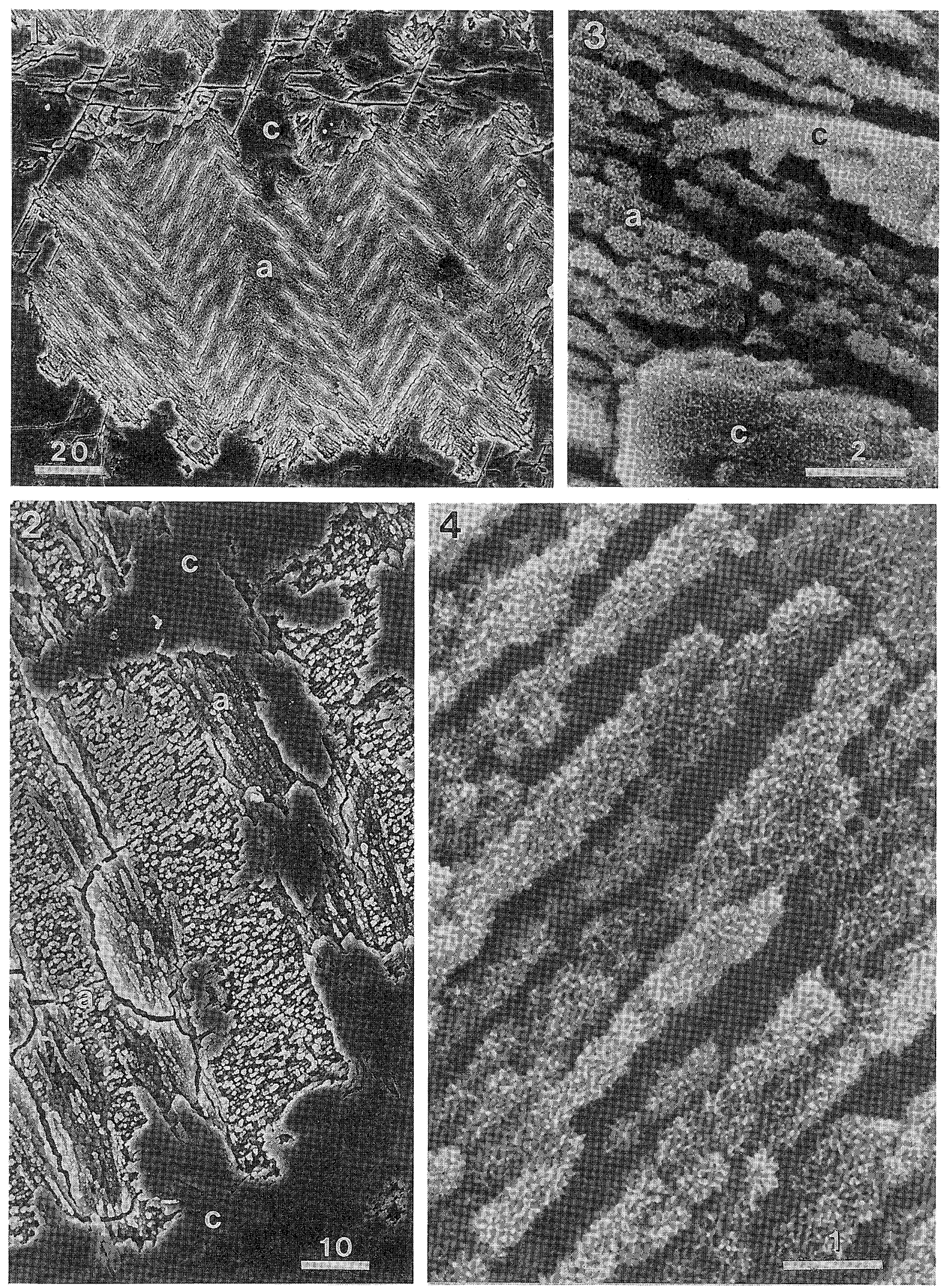

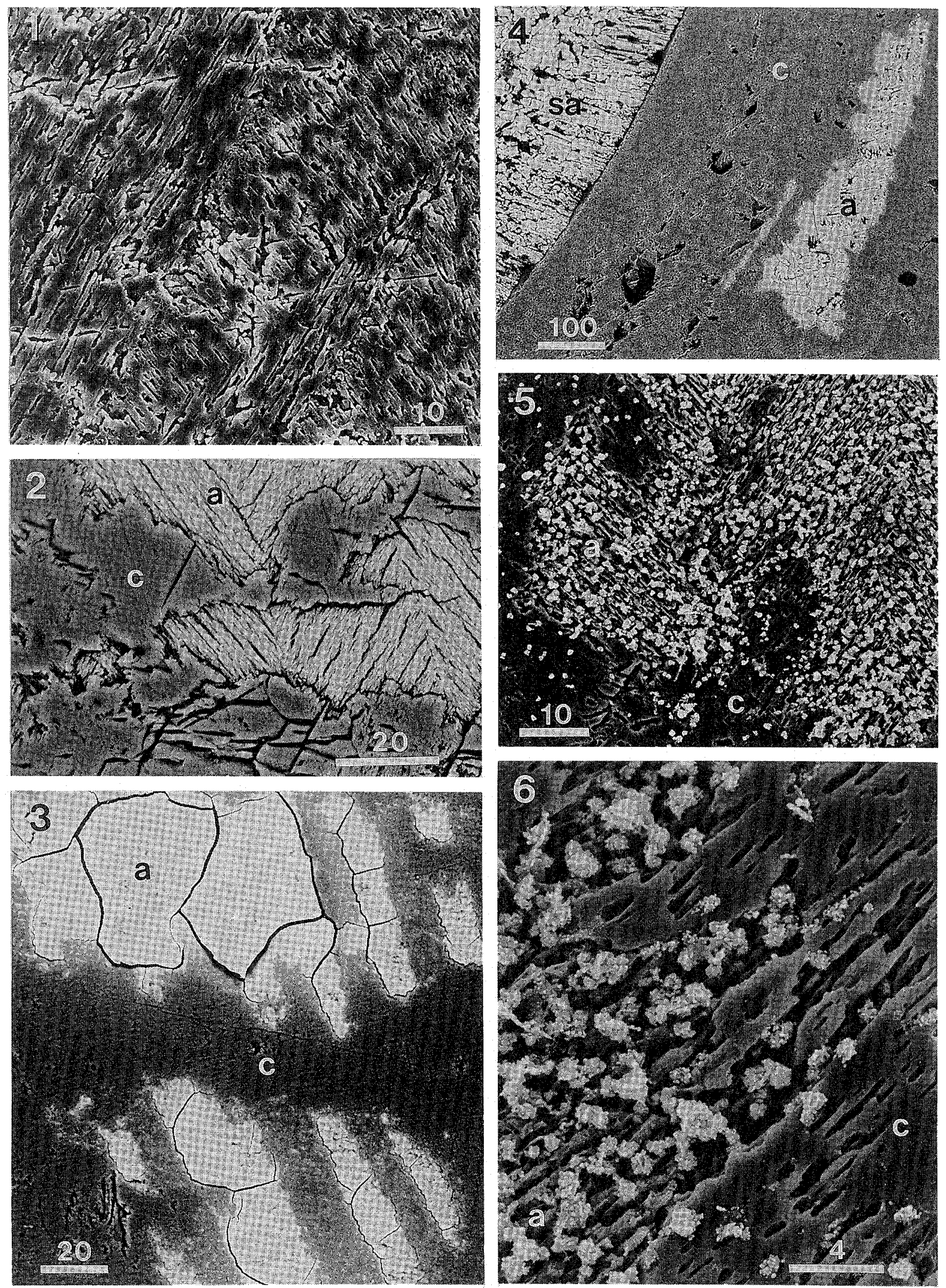

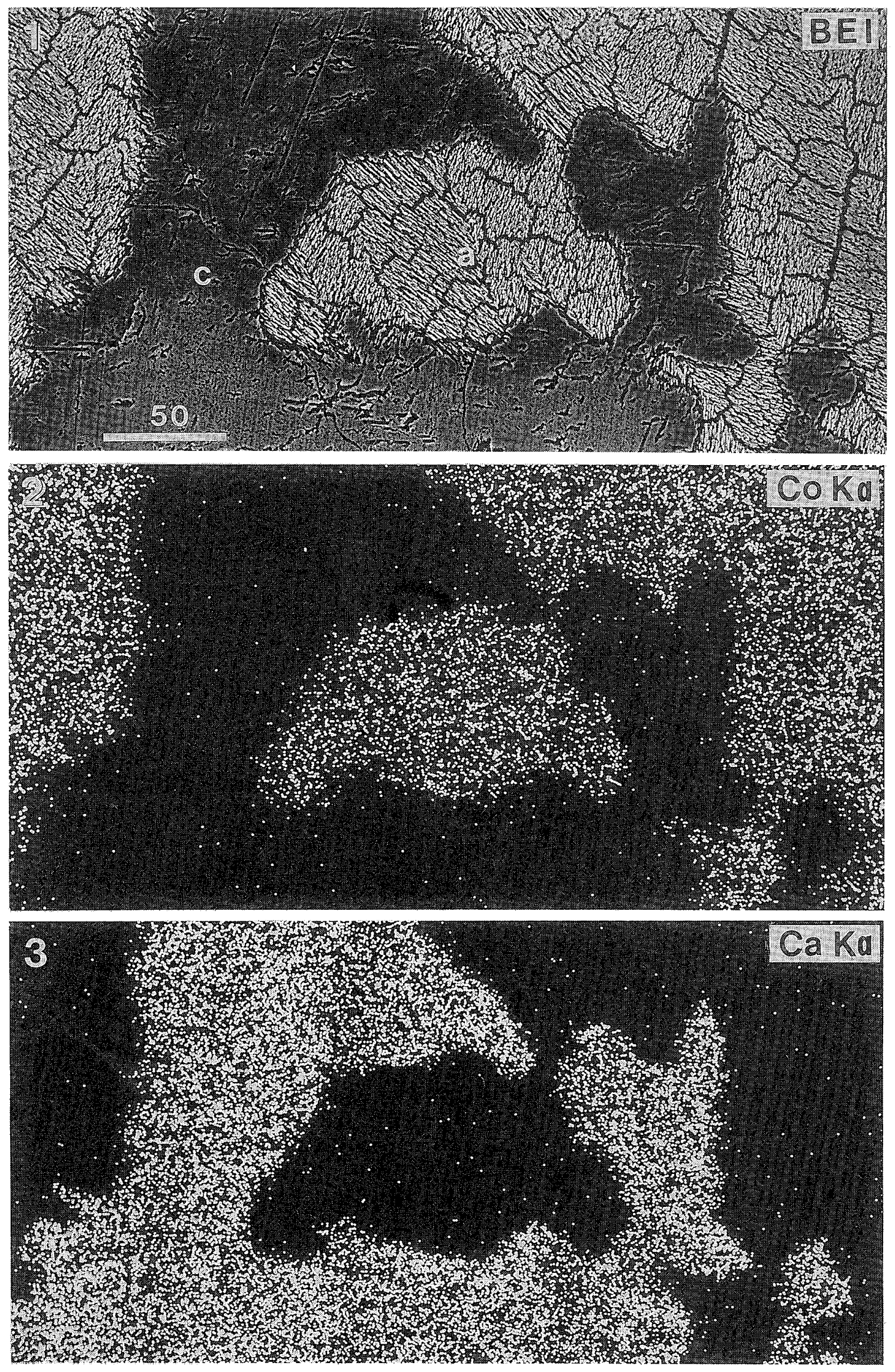